Journal of Education and Teaching Learning (JETL)

Vol. 3, No. 1, 1-9 (2020)

Journal Homepage: http://pusdikra-publishing.com/index.php/jetl

\title{
CURRICULUM PLANNING IN BOARDING SCHOOL TAHFIZIL QUR'AN ISLAMIC CENTER FOUNDATION
}

\author{
Muhammad Fuad Zaini', Mansur Hidayat Pasaribu² \\ Universitas Islam Negeri Sumatera Utara \\ fuadzaini06@gmail.com,mansyurhidayatpasaribu@gmail.com
}

\begin{abstract}
Abstrak
Research implementation of learning is taught by teachers who are under the responsibility of the parents. The author argues that the implementation of learning in the tahfizil quran pesantren gives birth to many students memorizing the Koran at a young age, it is all inseparable from a good curriculum, which includes careful curriculum planning, and curriculum planning which includes the formulation of tahfiz goals, tahfiz material, and evaluation. tahfiz. Although there are several obstacles, namely teachers who teach tahfiz are not from the teacher faculty. research method used in this research is the case study method. A case study ( Case Study) is a study conducted in an incentive, detailed and indepth manner towards an organization, institution or specific phenomenon. According to Nasution, a case study is a form of research that can be carried out on an individual, a group of individuals, a human group (teacher, ethnic group), human environment (village), or social institutions. Result is Curriculum planning at the Islamic boarding school Tahfizil quran foundation is the realization of people who memorize and have the insight of the Qur'an and have a spiritual, intellectual, and moral balance towards a generation that is civilized by the Qur'an, highly committed to actualizing the teachings of the Al-Qur'an. -Qur'an and beneficial to society. Materials for learning at the Islamic Center foundation pesantren are for SD mainimal $5 \mathrm{Juz}$, while for Madrasah Tsanawiyah for class VII 5 Juz, for grade VII 10 Juz and for grade IX 15 Juz, Madrasah Aliyah 20 to 25 and for Madrasah Tahfizhil Quran are the targets. 30 juz. In the Tahfizil quran Islamic boarding school there are several methods used, namely: the si'maan method (listening to memorization), the quiz method (giving questions), the splicing method, the talaqqi method and the sorongan method. Target achievement of 2 years 30 chapters with the burden of learning 4 hours / day. And the learning schedule, from morning to dawn until 7 o'clock, and the target is 1 to 2 pages per day (10 to 20 days 1 juz, only then 10 days for memorizing muraja'ah. Evaluation of learning in the tahfizhil quran pesantren by looking at the progress of the students' memorization.Implementation of learning is the process of the learning implementation plan (RPP) which includes preliminary activities, core and pentup activities. In this Islamic boarding school specifically for the tahfizil Quran, it does not use money.
\end{abstract}

Key Word : Curriculum, Islamic Boarding School, Tahfizhil Qur'an

\section{PENDAHULUAN}

National education based on the 1945 Constitution of the Republic of Indonesia functions to develop capabilities and shape the character and civilization of the nation with dignity in order to educate the nation's life, aiming to develop the potential of students to become human beings who believe and 


\section{Curriculum Planning In Boarding School Tahfizil Qur'an Islamic Center Foundation}

have faith in Allah SWT, with noble character, healthy, knowledgeable, capable, creative, independent, and become democratic and responsible citizens. To develop this function, the government implements a national education system as stipulated in Law Number 20 of 2003 concerning the national education system. One of the educational institutions that can play a role in carrying out the government's aspirations is the Islamic boarding school which is a religious education institution, this is in accordance with Article 30 paragraph 4 of Law Number 20 of 2003 which explains that religious education is in the form of diniyah education, pesantren, and other forms of education. others of a kind. The term pesantren in Indonesia is more popularly known as pondok pesantren, unlike pesantren, pondok comes from the Arabic word which means hotel, dormitory, house and simple residence. Islamic boarding schools are traditional Islamic institutions for studying, understanding, living and practicing Islamic teachings by emphasizing the importance of religious morals as guidelines for daily behavior. The purpose of education in boarding school is to guide students to become human personality Islam, students with religious knowledge, able to be preachers in society About a $r$ through science and religion. In the era of globalization, there have been many changes, especially in the field of education. Many parents don't pay attention to their children for various reasons, such as being busy with their work, so that many children fall into promiscuity, drugs, and so on. Parents are also weak in terms of supervision and are reluctant to enroll their children in Islamic boarding schools. Problems like this require an educational institution with good management that is able to produce students who are faithful, devoted, have good character, are independent, as stated in the goals of national education that can be achieved. . For this reason, it is necessary to have an educational institution with a well-structured curriculum.

As an original Indonesian Islamic education institution, Islamic boarding schools have shown success in maintaining their existence. From the pre-independence era to the Reformation Order, Islamic boarding schools were increasingly recognized in Indonesian legislation, especially in relation to education. As an Islamic educational institution, pesantren has elements of kyai, santri, boarding schools, mosques, learning methods and the yellow book. The Islamic boarding school varies into salafiyah and khalafiyah. But both of them still use the three learning methods, namely sorogan, bandongan and wetonan. The pesantren curriculum is a tool to achieve educational goals, as well as a guide in the implementation of education that reflects the nation's view of life. The education policy environment is the scope that is in the environment of the education system, both centralized and local in nature. The issues and agenda of education policy consist of issues that are being seriously discussed in the relationship between policy domains in education. Education policy formulation systems and procedures include the allocation function, inquiry function and communication function. The study of methodology in education policy cannot be separated from a discussion of the substance of education 


\section{Curriculum Planning In Boarding School Tahfizil Qur'an \\ Islamic Center Foundation}

itself. Pesantren - although it is a model of indigenous education - but in its dynamics it is always inseparable from the national education policy. ${ }^{1}$

As a boarding school which is under the auspices of a Madrasah, the curriculum being developed is certainly different from other Islamic boarding schools in general. The curriculum for the salafi Islamic boarding school is compiled by the kiai or the head of the boarding school which is based on the needs of the general public regarding worship and mu'amalat, as well as the kiai's competences. The curriculum of pondok pesanten salafi, Kresek sub-district, Tangerang district consists of intracurricular, co-curricular and extracurricular activities. Intrakurikuler in Pondok Pesanten Salafi curriculum which specifically teaches vocational materials. While the intracurricular in the Pondok Pesanten Salafi curriculum which is mixed is to teach all fields of religious scholarship from fiqh, hadith, tafsir to tauhid. The focus of emphasis on the co-curricular curriculum for salafi pesanten and mixed salafi co-curricular curricula are several fields of science that include; nahwu science, neuroscience, balaghah science and also logic. In order to channel the talents and interests of the extracurricular santri, the salafi pesanten curriculum includes; nasyid activities, marawis, jam'iyah al-qurra 'tahlilan, and also penca silat.

First, the implementation of the development of the Madrasah Tsanawiyah education curriculum at the Nurul Huda Al-Islami Islamic Boarding School includes several main components, namely the objective components of the pesantren curriculum; namely "so that students are able to understand the science of 'tools, in order to deepen Islamic law in classical books in the learning process, Material; Basically the material or content of the Islamic boarding school curriculum implemented at the Nurul Huda Al-Islami Islamic boarding school can be classified into three categories, it is not at all related to the curriculum of the Ministry of Religion, has something to do with the curriculum of the Ministry of Religion, and is closely related to the curriculum of the Ministry of Religion, the method used in the learning process varies the emphasis is more on memorization and evaluation methods which are carried out by rote daily, weekly tests called deposits and semesters. Broadly speaking, the factors that influence the implementation of the curriculum at Madrasah Tsanawiyah Pondok Pesantren Nurul Huda Al-Islami can be grouped into two factors, namely internal factors and external factors. Internal factors include: caregiver initiatives, the desire of teachers to increase the efficiency and effectiveness of teaching in the pesantren, and the desire to have out put or alumni ready to use in the community. While the external factors are: The development of science and technology and the influence of the dynamics of the education system in general is getting more and more advanced. Pesantren tahfizhil quran Foundation isl a mic center has a mission to build a generation that memorizes the Al-Qur'an and has good morals in accordance with Islamic teachings, Educates generations to have the ability to read the

\footnotetext{
${ }^{1}$ Ahmad Saifuddin , Eksistensi Kurikulum Pesantren Dan Kebijakan Pendidikan ,Jurnal Pendidikan Agama Islam Volume 03, Nomor 01, Mei 2015
} 


\section{Curriculum Planning In Boarding School Tahfizil Qur'an \\ Islamic Center Foundation}

Koran and interpret the contents of the Qur'an, and an appeal to goodness and prevention of evil, Improving the quality of education in achieving academic and non-academic achievements, Implementing the values of the Qur'an in education and everyday life. ${ }^{2}$

According to the data the author got from the Islamic Boarding School, the Tahfizhil Quran Foundation, the Islamic Center Foundation, many of the students were invited to the mosque to become special imams in the month of Ramadan because they memorized 30 juz of the Koran. In addition, the learning process is also integrated with formal education, namely madrasah. The implementation of learning is taught by teachers who are under the responsibility of the parents. The author argues that the implementation of learning in the tahfizil quran pesantren gives birth to many students memorizing the Koran at a young age, it is all inseparable from a good curriculum, which includes careful curriculum planning, and curriculum planning which includes the formulation of tahfiz goals, tahfiz material, and evaluation. tahfiz. Although there are several obstacles, namely teachers who teach tahfiz are not from the teacher faculty.

\section{Planning}

Planning is one of the most important management functions. Especially in an educational institution, because it is a determining factor for the success of the goals to be achieved. Here are some expert opinions about planning. Oxford Advanced Learner's Dictionary of current English describes the meaning of planning as follows:

1. An outline description of a building, both size, position, and various other parts.

2. Machine parts diagram

3. A diagram showing the size of a garden, park, city, or land area

Arrangement of something that must be done and used (arragement for doing or using something) Stephen Robbins and Mary Coulter put forward many planning objectives. The first objective is to provide direction for both managers and non-managerial employees. With a plan, employees can know what they have to achieve, who they have to work with, and what must be done to achieve organizational goals. Without a plan, departments and individuals may work independently of each other, so that the work of the organization is less efficient. The second objective is to reduce uncertainty. When a manager makes plans, he is forced to look far ahead, forecast changes, estimate the effects of those changes, and devise plans for dealing with them. The third goal is to minimize waste. With directed and planned work, employees can work more efficiently and reduce waste. In addition, with a plan, a manager can also identify and remove things that can cause inefficiency in the company. The last objective is to set the objectives and standards used in the next function, namely the process of

\footnotetext{
${ }^{2}$ Kholis Thohir, Kurikulum Dan Sistem Pembelajaran Pondok Pesantren Salafi Di Kecamatan Kresek Kabupaten Tangerang Provinsi Banten, Analytica Islamica, Vol. 6. No. 1. Januari-Juni 2017
} 


\section{Curriculum Planning In Boarding School Tahfizil Qur'an \\ Islamic Center Foundation}

controlling and evaluating. The process of evaluating or evaluating is the process of comparing plans with existing realities. Without a plan, managers will not be able to assess the company's performance. ${ }^{3}$

\section{Curriculum}

The curriculum is a device provided by an educational institution which contains lesson designs that will be given to students in a period of education. Meanwhile, according to Rusman, the curriculum is a set of plans and arrangements regarding the objectives, content, and learning materials as well as materials used as guidelines for implementing learning activities to achieve certain educational goals. The National Education System Law Number 20 of 2003 explains that the curriculum is a set of plans and arrangements regarding the objectives, content, and learning materials as well as the methods used as guidelines for implementing learning activities to achieve certain educational goals 4

\section{Islamic Education Curriculum Components}

The curriculum component contains or consists of the following components:

\section{a. Destination}

Goals are a very important component in compiling a curriculum. The objective component relates to the direction or goals to be achieved in the delivery of education. Every curriculum planner must define the direction that education should aim for.

b. Contents

Content or subject matter is a component after the goal. In certain contexts, subject matter is at the core of the learning process. This content component shows the learning process material. The material (content) must be relevant to the learning objectives that have been formulated.

C. Methods in the Learning Process

Method is a component that also plays an important and very decisive role. The success of achieving goals is largely determined by this component. The learning method component considers the activities of children and teachers in the learning process. In the learning process, it should not be left alone, but educators have a very important role in achieving learning goals

d. Evaluation

\footnotetext{
${ }^{3}$ Muhlasin , Pelaksanaan Kurikulum Pesantren di Madrasah Tsanawiyah Nurul Huda AlIslami Kecamatan Marpoyan Damai Kota Madya Pekanbaru. PPs. UIN Suska Riau, 2011

${ }^{4}$ Sarbini, Neneng Lina, Perencanaan Pendidikan, Pustaka Setia:Bandung, 2011, hal 13 


\section{Curriculum Planning In Boarding School Tahfizil Qur'an \\ Islamic Center Foundation}

Evaluation is a part of the assessment to find out how far success is in achieving these learning objectives. Evaluation is the final step in the whole process. ${ }^{5}$

\section{RESEARCH METHODE}

According to Strauss and Corbin, qualitative research is a type of research in which the discovery procedure is carried out not using statistical or quantification procedures. In this case qualitative research is research on a person's life, stories, behavior, and also about organizational functions, social movements or reciprocal relationships. ${ }^{6}$ The research method used in this research is the case study method. A case study ( Case Study) is a study conducted in an incentive, detailed and in-depth manner towards an organization, institution or specific phenomenon. According to Nasution, a case study is a form of research that can be carried out on an individual, a group of individuals, a human group (teacher, ethnic group), human environment (village), or social institutions ${ }^{7}$

\section{RESULT AND DISCUSSION}

\section{Planning curriculum at the Tahfizhil Quran Islamic Center Foundation in North Sumatra}

Curriculum planning is the process of setting goals, objectives, and curriculum programs that guide the implementation of learning in achieving educational goals in schools. While the curriculum is a set of plans and arrangements regarding the content, objectives, and learning materials as well as the methods used as guidelines for implementing learning activities to achieve educational productivity. Planning curriculum here two kinds, there are curricula of formal and non-formal, intra curriculum, if the formal curriculum we were to follow the curriculum of the ministry of religion, if sd that we follow the curriculum of national education, IT was a specialist or specific filled by us, the primary school integrated Islam, still following the syllabus, rpp. What we plan to emphasize. We will emphasize the tahfizhil alQuran as the basis because from the beginning here it has been hafiz al-Quran. That is the basis, so we are based on memorizing the Koran, but in the middle of the way the students who memorized the Qur'an also wanted formal diplomas, finally we entrusted them to outside madrasas, so it was out of control, so we took the initiative to open a madrasah aliyah here in 2009. And in 2011 madrasah tsanawiyah and finally sd. And that's where we make the master plan for hafiz al-quran to finish at least 5 juz, and if he enters Tsanawiyah he just adds 10 juz to 15 juz. But the minimum can be achieved, not all of them reach 30 juz, but many of the children have memorized 10 juz graduated from Tsanawiyah. So, there are two kinds of curriculum at the Islamic Center Islamic Center's Tahfizhil Quran Islamic

\footnotetext{
${ }^{5}$ Rusman, Manajemen Kurikulum, Jakarta: PT. Raja Grafindo Persada, 2009, hal 3

${ }^{6}$ Sugiyono, (2015) Metode Penelitin Kuantitatif, Kualitatif, Dan Kombinasi(Mixed Methods) Bandung: Alfabeta, , h. 309-326.

${ }^{7}$ Suharsimi Arikunto, (2013) Prosedur Penelitian: Suatu Pendekatan Praktik . Jakarta: Rineka Cipta, , h. 198.
} 


\section{Curriculum Planning In Boarding School Tahfizil Qur'an \\ Islamic Center Foundation}

boarding school, namely the formal and informal curriculum. The formal curriculum is based on the Ministry of Religion, while the one compiled and planned by the pesantren is an informal curriculum that is focused on tahfizhil Quran.

\section{Formulation of curriculum planning objectives at the Islamic Center Foundation's Tahfizhil Quran Islamic Boarding School}

In 1980, the progress of the development of Islamic civilization in Indonesia experienced a very significant increase with the proliferation of Islamic boarding schools, both classical and modern and the establishment of a center for spreading Islamic da'wah known as the Islamic Center which functions as an Islamic information center in the regions. Goals are a very important component in compiling a curriculum. In formulating goals in an educational institution, it cannot be separated from the vision and mission. Vision is the idea of the main goal, then mission is the stages that must be passed to achieve that vision. The vision and mission of the Islamic Center Foundation's Tahfizhil Quran Islamic Boarding School are:

\section{Vision}

"The realization of a person who memorizes and has the insight of the Qur'an and has a spiritual, intellectual and moral balance towards a generation that is civilized by the Koran, is highly committed to actualizing the teachings of the Qur'an."

\section{Mission}

- The formation of a generation that memorizes the Al-Qur'an and has good morals in accordance with the teachings of the Islamic religion.

- Creating students with the ability to insight into the Qur'an , as an interpretation of the contents of the Al-Qur'an, and call for goodness and prevention of evil.

- Education that prioritizes quality in achieving academic and non-academic achievements.

The goal is the realization of hafiz and hafizah as guardians of the purity of the Koran, so that Indonesia does not lack the spirit of the Koran that we hope for, and Alhamdullah when it is fasting, many hafiz are used in mosques, one mosque has two people, because the one becomes the priest who the other protects and can be repaired, so the goal is to become human beings with good character. Curriculum planning at the Islamic boarding school Tahfizil quran foundation is the realization of people who memorize and have an insight into the Koran and have a spiritual, intellectual, and moral balance towards a generation that is civilized by the Qur'an, is highly committed to actualizing the teachings. teachings of the Koran and benefit the community.

\section{Curriculum Contents and Methods in the Learning process}

Content or subject matter is a component after the goal. The content component shows the learning process material. Learning materials must be in accordance with the educational goals that 


\section{Curriculum Planning In Boarding School Tahfizil Qur'an \\ Islamic Center Foundation}

have been formulated. The contents of the curriculum at the Tahfizhil Quran Islamic boarding school based on the results of the interview are "The material is Al-Quran, "The goal is clear hafizh al-Quran 30 Juz, especially in Madrasah Tahfizhil Quran with a target of achieving 2 years 30 juz " material for learning at the Islamic Center foundation pesantren is for SD mainimal 5 Juz, while for Madrasah Tsanawiyah for class VII 5 Juz, for grade VII 10 Juz and for grade IX 15 Juz, Madrasah Aliyah 20 to 25 and for Madrasah Tahfizhil Quran i.e. the target is 30 juz.

Methods are the right and fast way of doing something. Zuhairi stated that the method can be interpreted as the right and fast way to apply the memorization method in teaching. Metode it is up to the teacher, methods and method talaqqi shove it heard by the teacher, and then in the love of a new paragraph, if the Tahfiz it a lot more guidance There are several methods of memorizing the Koran, including: the method of memorizing the Qur'an is the right and fast way to enter information in the form of verses of the Qur'an, can save it and can also convey it back by heart . In the Tahfizil quran Islamic boarding school there are several methods used, namely: the si'maan method (listening to memorization), the quiz method (giving questions), the splicing method, the talaqqi method and the sorongan method.

\section{Implementasi curriculum in boarding Tahfizhil Quran Foundation of Islamic Center of North Sumatra}

The implementation of the curriculum and learning is the realization of the curriculum which is still a written document to become actual in a series of learning activities. Curriculum implementers are teachers who are given the mandate to teach and educate students. Based on the observations there are two models of learning implementation, namely tahfiz al-quran and formal schooling. Based on the results of interviews with teachers and pesantren leaders, the target is 2 years 30 juz with a learning load of 4 hours / day. And the learning schedule, from morning to dawn until 7 o'clock, and the target is 1 to 2 pages per day (10 to 20 days 1 juz, only then 10 days for memorizing muraja'ah. The implementation of learning is the process of the learning implementation plan (RPP) which includes preliminary activities, core and pentup activities. In this Islamic boarding school specifically for tahfizil Quran, it does not use rpp. In implementing the learning curriculum, there are several obstacles faced in implementing the curriculum, namely that there are some educators who are not from a tarbiyah background

Evaluation is a part of the assessment to find out how far success is in achieving these learning objectives . Curriculum evaluation plays an important role, both for determining educational policy and for making decisions in the curriculum itself. Evaluation of teachers, but now we have had the chain of transmission, means of connection with the Messenger, the Prophet gave to his friend, then the friend gave to tabi'in continued, and new aj sanad there Evaluation by looking at the development of students' 


\section{Curriculum Planning In Boarding School Tahfizil Qur'an \\ Islamic Center Foundation}

memorization. Evaluation of learning in the tahfizhil quran pesantren by looking at the development of memorizing the students

\section{Conclusion}

Curriculum planning at the Islamic boarding school Tahfizil quran foundation is the realization of people who memorize and have the insight of the Qur'an and have a spiritual, intellectual, and moral balance towards a generation that is civilized by the Qur'an, highly committed to actualizing the teachings of the Al-Qur'an. -Qur'an and beneficial to society. Materials for learning at the Islamic Center foundation pesantren are for SD mainimal 5 Juz, while for Madrasah Tsanawiyah for class VII 5 Juz, for grade VII 10 Juz and for grade IX 15 Juz, Madrasah Aliyah 20 to 25 and for Madrasah Tahfizhil Quran are the targets. 30 juz. In the Tahfizil quran Islamic boarding school there are several methods used, namely: the si'maan method (listening to memorization), the quiz method (giving questions), the splicing method, the talaqqi method and the sorongan method. Target achievement of 2 years 30 chapters with the burden of learning 4 hours / day. And the learning schedule, from morning to dawn until 7 o'clock, and the target is 1 to 2 pages per day (10 to 20 days 1 juz, only then 10 days for memorizing muraja'ah. Evaluation of learning in the tahfizhil quran pesantren by looking at the progress of the students' memorization.Implementation of learning is the process of the learning implementation plan (RPP) which includes preliminary activities, core and pentup activities. In this Islamic boarding school specifically for the tahfizil Quran, it does not use money.

\section{Reference}

Ahmad Saifuddin , Eksistensi Kurikulum Pesantren Dan Kebijakan Pendidikan ,Jurnal Pendidikan Agama Islam Volume 03, Nomor 01, Mei 2015

Kholis Thohir, Kurikulum Dan Sistem Pembelajaran Pondok Pesantren Salafi Di Kecamatan Kresek Kabupaten Tangerang Provinsi Banten, Analytica

Muhlasin , Pelaksanaan Kurikulum Pesantren di Madrasah Tsanawiyah Nurul Huda Allslami Kecamatan Marpoyan Damai Kota Madya Pekanbaru. PPs. UIN Suska Riau, 2011.

Sarbini, Neneng Lina, Perencanaan Pendidikan, Pustaka Setia:Bandung, 2011.

Rusman, Manajemen Kurikulum, Jakarta: PT. Raja Grafindo Persada, 2009.

Sugiyono, (2015) Metode Penelitin Kuantitatif, Kualitatif, Dan Kombinasi(Mixed Methods) Bandung: Alfabeta

Suharsimi Arikunto, (2013) Prosedur Penelitian: Suatu Pendekatan Praktik . Jakarta: Rineka Cipta

Zaini, M. F. (2019). The Implementation Of Learning Management In Class VIII Madrasa Tsanawiyah Islamiyah (Mts) Ypi Batangkuis. International Conference on Islamic Educational Management (ICIEM). 